\title{
Sex Education Correlating with STI Rates Throughout Counties in Florida
}

\author{
Lilliana Moran $^{1}$ and Ida Williams ${ }^{1}$
}

${ }^{1}$ Western High School, Davie, FL, USA

\section{ABSTRACT}

This study's goal was to discover the impact that varying types of high school sex education curriculums had on the rate of which their alumni ages 19-27 in 2018 contracted bacterial sexually transmitted diseases (STDs) throughout counties in Florida. The study was able to establish results that communicated which programs were most effective in preventing the transmission of STDs in comparison to the ones that were least effective. A meta-analysis of the amount of bacterial STD cases in each of four different counties in Florida as well as their corresponding sex education curriculum was used to discover the paper's outcome. The different curriculums analyzed in this paper include abstinenceonly, abstinence-plus, and comprehensive. Abstinence-only based programs teach students that refraining from all sexual activity until marriage is the sole moral way of preventing STD transmission and generally does not go over other methods of contraceptives. Abstinence-Plus programs teach students about methods of contraception and how to prevent STDs, but still preach that remaining abstinent is the correct and moral route to go down. The results showed that Lafayette County and Martin County had the least amount of bacterial STD cases among their alumni ages 19-27 yet used the most strict program (abstinence-only), Orange County had the most amount of bacterial STD cases among their alumni and used the second most strict program(abstinence-plus), and Polk County's amount of bacterial STD cases fell under Orange County but above Lafayette County and Martin County; however they used the least strict program (comprehensive).

\section{Introduction}

Sex; a normal part of life that is commonly experienced within one's time on Earth regardless of race, gender, sexual orientation, or religion. Depending on what sexual orientation someone classifies themselves as or what birth control methods they may use, they may believe they can lead their sex life care free. Nevertheless, even if certain people are protected against unwanted pregnancies, everyone is susceptible to sexually transmitted diseases (STDs). In the United States alone there were over 2.3 million cases of bacterial STD cases recorded in 2018 (CDC). Bacterial sexually transmitted diseases are limited to Chlamydia, Gonorrhea, and Syphilis. Other commonly known STDs such as Herpes, Human Immunodeficiency Virus (HIV), Human papillomavirus (HPV), and Hepatitis C fall into the classification of viral STDs. One major difference between viral and bacterial STDs is that viral sexually transmitted diseases can never be completely cured, while doctors can prescribe medicines to help subdue a patient's symptoms, they will never be completely free of the STD (medlineplus.gov, 2017). 
With that said, the proper and effective implementation of sex education can help slow trasmission rates of STDs. Currently, the United States employs three main sex education curriculums throughout the country's school systems: Abstinence-Only, Abstinence-Plus, and Comprehensive (Blanton, 2019). Abstinence based programs focus on teaching others that refraining from engaging in sexual activity is the only moral way to be protected from sexually transmitted diseases. Not to mention, in return they do not teach people about alternative contraceptive methods that prevent STDs, such as condoms. Abstinence-Plus programs focus on educating people about methods of contraceptives that will prevent the contraction of STDs; however, they still preach that remaining abstinent is the proper route to follow. Comprehensive curriculums go one step further and teach people about all the different ways to prevent STDs and normalize sexual activity instead of stigmatizing it as something impure if done out of wedlock. Sexual education classes impact the children who sit through them in school from the moment they receive them to later on in life. Those programs are meant to teach people lifelong knowledge and skills they will hold onto forever, and so what is taught in those programs can impact a person's life. The goal of this research paper is to determine how different high school sex education programs used in counties throughout Florida correlate with the number of STDs present in their alumni who were ages 19-27 in the year of 2018. After carrying out the experiment, I predict that the counties who employ abstinence only based curricula will have the highest rates of STDs in their alumni compared to abstinence plus programs and comprehensive programs. The comprehensive programs specifically should show the least amount of STD cases in their alumni after examination.

\section{Literature Review}

The United State's current situation, in terms of the spread of sexually transmitted diseases, has not improved over the past decade. It is assumed that due to new technology and better access to information that the numbers of STDs in the US would decline; however, according to the CDC, the cases in 2018 have risen well above the amount of cases in 2013; going from 1.8 million to 2.4 million. Around half of those cases belong to America's youth alone (US Department of Human Health, 2019). The most common STD in America is the Human papillomavirus, also known as HPV. As of 2019, according to the CDC, about 79 million people in America suffered from HPV and its devastating effects. Some of which include genital warts and various cancers, such as cancer of the vagina, cervix, penis, anus, and throat. Sexually transmitted diseases can also be transferred to the newborn babies or fetuses of infected mothers. The STD can be relayed to the child when they pass through a contaminated birth canal or even before they are born in some cases when the mother suffers from human immunodeficiency virus (HIV), Cytomegalovirus (CMV), or Syphilis (March of Dimes, 2018). This becomes a problem for the mother and child because occasionally STDs can cause complications such as miscarriages, birth defects, early labor and delivery, and illness within the newborn.

To better understand the statistics collected in the United States this field of study presents, it is crucial to be informed about what sex education policies are instated. Going back in time, the US began its crusade to sexual health knowledge in 1990s when the federal government adopted and funded an abstinence only until marriage (AOUM) sex education program as part of the "welfare reform" (Hall et al., 2016). In the 2000's, during President Bush's time in office, another sex education initiative that was centered on abstinence, titled the Community-Based Abstinence Education (CBAE) program, was also federally funded, despite evidence of abstinence education being inneffective (Boonstra, 2009). The United State's government continually endorsed these abstinence based programs when the 
funding increased to eighty five million dollars per year in 2016 under Obama's presidency in defiance of him trying to end the program. The Sexuality Information and Education Council of the United States has confirmed that as of 2018, 21 states did not require any sex education or STD/HIV information to be medically accurate or evidence based; 16 states required condom or contraception instruction provided when STD/HIV information is delivered; and 32 states required to emphasize abstinence during sex education instruction. A study conducted by two University of Georgia students, Kathrin F. Stanger-Hall and David W. Hall, in 2011 revealed that states with laws and policies focusing more on abstinence only education rather than comprehensive programs showed higher rates of teen pregnancies and STDs. Their study also concluded that students who participate in comprehensive education make safer choices when engaging in sexual activity and feel better informed. This study in particular created more opportunities in the field for researchers to further explore how sex education policies affected students on smaller scales. A similar study conducted by Georgia State University Student Valerie Masutier in 2017 revealed that the Georgia public school sex education system, which is abstinence based, proved ineffective "at preventing STIs and promoting safe sex practices." Masutier's study coincides with the results of Stanger-Hall and Hall's study by validating their results indirectly. Since Stanger-Hall and Hall discovered that states with school sex education policies centered around abstinence have higher STD and teen pregnancy rates, and the state of Georgia where Maustier conducted her study has state education policies focusing on abstinence as well as high STD rates, they validate each other. Contrary to the previous studies mentioned, a study published in the Archives of Pediatrics and Adolescent Medicine by the American Medical Associaltion came to conclusive results that abstinence programs "reduced sexual initiation" amidst the group of Afircan-American adolescents they were observing (Jemmott et al., 2010).

Compared to Florida's previous years, statistically speaking, the state's rates of new sexually transmitted disease cases in recent times show a horrifying increase (Gross, 2017). Sex education is partially to blame for this increase in STDs. More specifically, the lack of education itself. The Florida Department of Education allows sex education to be determined by the district level and so various school districts can employ abstinence-only, abstinence plus, or comprehensive programs; however, all programs must preach abstinece, even the comprehensive ones (2020). After thoroughly researching the field, no data was found about specific counties in Florida and their STD rates correlating with education in recent years. From there, I was able to form a question that had not been previously addressed. I will employ a meta-analysis to answer the question: to what extent do varying sex education programs across school districts in Florida correlate with STD rates in their alumni ages 19-27?

\section{Methods}

In order to determine how different sex education curriculums correlate with previous students' rates of contracting various bacterial STDs ages 19-27 in 2018 through numerous school districts, I conducted a meta-analysis. The age group focused on in my research was selected based on how far back the data given to me by all 4 counties went. My research began by searching for all the school district websites and varying curriculums of the 8 counties I originally selected: Brevard, Broward, Collier, Duval, Martin, Miami Dade, Sarasota, and St. Johns; however, I had to contact over 20 counties only to receive data from 4 with the information necessary. The counties I would later analyze included Lafayette, Martin, Orange, and Polk. The analysis focused on high school graduate classes from 2009 all the way to 2017. Following that, I read each county's curriculum and organized all of them into a chart, discovering which 
counties had more conservative programs (abstinence-only), which counties considered themselves abstinence-plus, and which had more liberal programs (comprehensive). In accordance with qualifications from the Advocates for Youth organization, abstinence-only curricula were defined by teaching abstinence as the singular morally correct option and teaching little to nothing about other contraceptive methods, abstinence-plus programs were defined by including information about various contraceptive methods but focusing strongly on preaching and advocating for abstinence, and comprehensive programs were defined by their mentioning of abstinence as the best way to avoid STDs but also including various contraceptive methods without a moral bias detected. After examining and categorizing the curricula, I utilized the data collected on Bacterial STD rates in the year of 2018 by county and age group in Florida published by FLHealthCharts.com. All of the data sourced from FLHealthCharts.com was supplied by the Florida Department of Health, Bureau of Communicable Diseases and is both highly accurate and credible. While analyzing the data, in order to follow the same graduate classes of 2009-2017, I adjusted the minimum and maximum ages of 19-27 down a year for every year under 2018 I observed. Since the most recent data concerning the bacterial STD rates by county was published in 2018, my research focuses on people who were 19-27 during the year of 2018. To put into perspective, that group of individuals would change to 21-29 if the statistical data were published in 2020. Continuing, I then started to organize the data to depict the varying ages, their STD receival rate, and location of the county for all five areas into another document. The location was determined by a map of Florida's regions provided by a study done by Dr. Stanley K. Smith from the University of Florida in 2005. Once the data was neatly organized, I searched for patterns, trends, and correlations. Trends and patterns I expected to find include an increase in STDs with a decrease of fact based knowledge (more conservative programs) and vice versa; however, I had to compare the statistical data and curriculum types before finding conclusive results. No interviews or surveys were conducted during my research, all of the results were forged from data gathered via the worldwide web.

A meta-analysis conducted in the manner stated above is the most effective approach to answering my research question because it takes into account all of the information available to students learning from different curriculums. A study in 2002 that focuses on measuring the effectiveness of the promotion of abstinence in students behavior provided my own research with a foundation to apply (Silva). Originally a survey was solely going to be conducted to figure out the correlations my question seeks to uncover; nonetheless, after further consideration and research it was concluded that if a survey had only been conducted, then the correlations would have been based on the alumnis memory of the curriculum rather than the information they are completely given access to. The entire goal of my research project is to find the correlations between the various curriculums and the information they offer their participants rather than what their previous participants remember.

Ideally, I desired to present a survey to the alumni ages 19-27 from the various counties, except, my institution did not allow me to survey the alumni that participated in the programs because inquiring about their personal sexual practices is considered unethical. Another limitation involving my method was the COVID-19 outbreak. It prevented me from travelling up to Marion County to review their sex education textbook. Marion County was unable to send it online, so the county was completely eliminated from my research. 


\section{Results}

The 4 counties being analyzed yielded a variation of sex education program types. Out of Lafayette, Martin, Orange, and Polk County, it was found that there were two abstinence-only programs, one abstinence-plus program, and one comprehensive program that were taught to the alumni ages 19-27. Table 1 communicates these findings in a more specific manner and takes note of the general region each county is located in as well.

Table 1

\begin{tabular}{|c|c|c|}
\hline County & Sex Education Program & Region \\
\hline Lafayette & Abstinence-Only & North Florida \\
\hline Martin & Abstinence-Only & Southeast Florida \\
\hline Orange & Abstinence-Plus & Central Florida \\
\hline Polk & Comprehensive & Central Florida \\
\hline
\end{tabular}

There is a correlation between the type of program used and the amount of bacterial STDs the alumni of these counties ages 19-27 contracted. Lafayette and Martin county both had strict abstinence-only curricula that did not educate their programs' participants on how to use preventative measures to combat STDs, yet they showed the lowest numbers by far in bacterial STD rates within the graduate classes of 2009-2017. Orange County implemented an abstinence-plus program and the alumni ages 19-27 exhibited the highest number of bacterial STD rates in comparison to the other counties. Lastly, Polk County was the only county with a comprehensive program and displayed the second highest amount of bacterial STDs in their alumni. In comparison to Florida's average amount of bacterial STDs in 2018 for people ages 19-27, Lafayette County and Martin County fall well below the average, Orange County is above the average and Polk County represents the average almost perfectly (Figure 1). 


\section{Comparison of Bacterial STD Rates in People Ages 19-27}

\section{8}

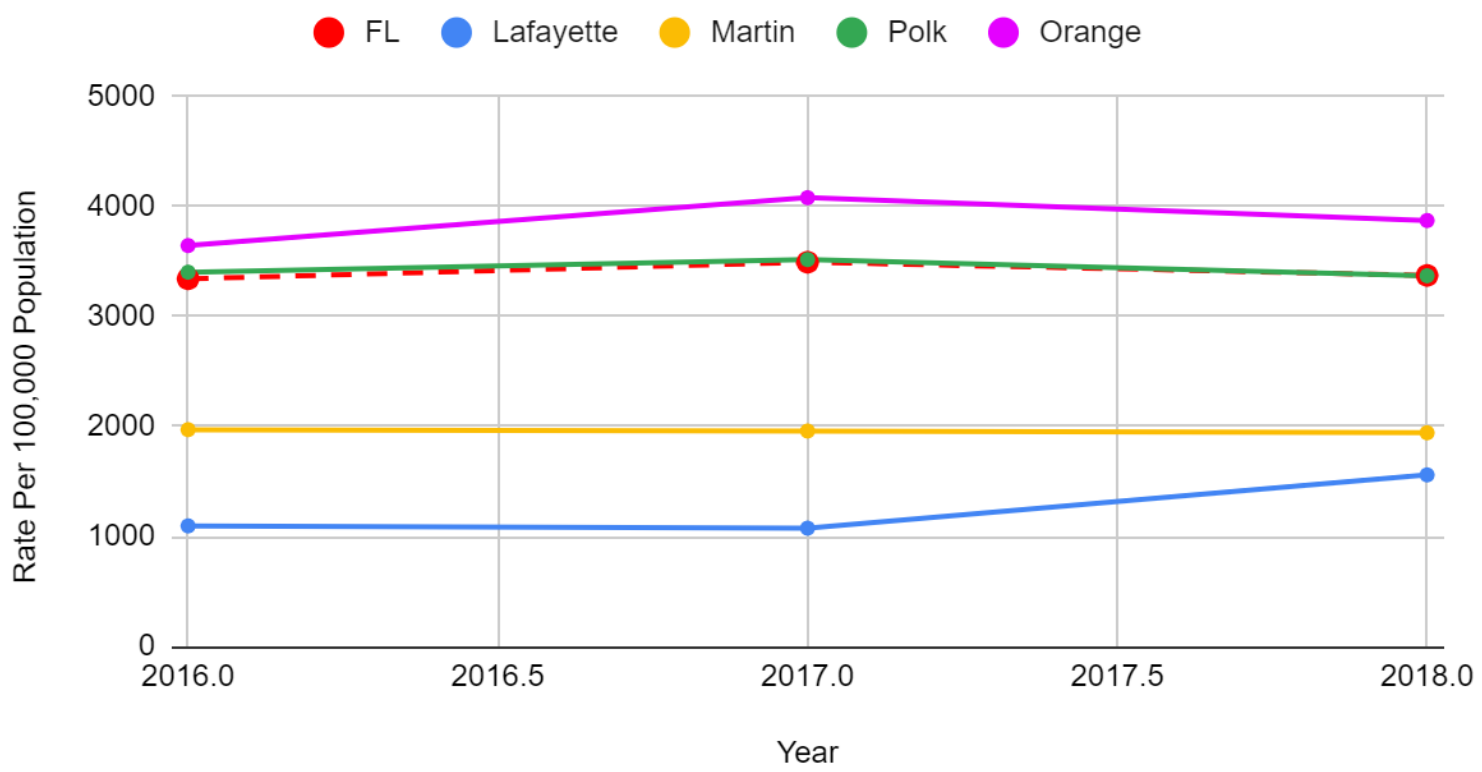

Figure 1: Information sourced from FLHealthCharts.com, 2020

The major trend discovered was the correlation between strict abstinence-only curriculums presenting lower rates of bacterial STDs when being compared to curriculums that actually introduced methods to prevent the transmission of bacterial STDs (abstinence-plus and comprehensive curriculums). In addition, there was a relationship between the location of the counties and the influence religion may have had on the bacterial STD rates. More specifically, Lafayette County and Martin County are both located farther north and were more susceptible to religious influence than their centrally located counterparts: Orange County and Polk County.

\section{Lafayette County}

After reviewing Lafayette County's curriculum, it has been determined that this county used an abstinence only curriculum to teach its alumni ages 19-27. Lafayette County used "A.C. Green's Game Plan" by Scott Phelps as their curriculum in order to teach the graduate classes of 2009-2017. This program proudly proclaims itself as a strict abstinence-only resource for learning and after the reviewal process I found it to be exactly what it claims. Throughout the whole student booklet, the term "abstinence" was written 44 times compared to the 4 times the term "condom" was written. In all of the scenarios throughout the booklet, a negative connotation is associated with the teens who decided to be sexually active and a positive connotation is associated with those who remained abstinent. That was concluded after an analysis of each individual scenario, which displayed that teens who were sexually active were in a worse mental state than those who remained abstinent. Moreover, when educating the students on STDs and preventative measures, the curriculum remained very biased and did not cover much. Meaning, although it did mention condoms, all of the content connected to them pointed out how they are never a guarantee and suggested that they are somewhat ineffective. The sex education program explicitly states "condoms have not been consistently proven 
effective in preventing HPV," and "some of the most common STDs are contracted from 'skin to skin' or 'skin to sore' contact on areas not covered by a condom." Although both of these statements are true, the curriculum fails to mention the other side of the argument: how effective condoms can be in preventing STDs when used properly. Also, the curriculum asks students to answer a series of yes or no questions that inquire whether or not condoms offer protection from a series of "emotional consequences," "mental consequences," and "social consequences listed." By including such questions based in feeling and emotion instead of the intended purpose of condoms, the curriculum is actively urging students towards abstinence alone and failing to educate them about the uses condoms are genuinely meant for. Basically, Lafayette County's curriculum in place to educate those between ages 19-27 clearly advocated for abstinence and did not inform its participants about proper preventative measures for sexually transmitted diseases. Subsequently, when differentiating between Lafayette County's rate of Bacterial STDs and Florida's rate for the graduating classes of 2009-2017, Lafayette's were discovered to be less than half of Florida's (Table 2). This extreme difference puts into perspective the effectiveness of an abstinence-only curriculum (Figure 2).

Table 2

\begin{tabular}{|c|c|c|c|c|}
\hline \multicolumn{6}{|c|}{ Bacterial STDs, Ages 19 - 27, Rate Per 100,000 Population, Single Year } \\
\hline & Lafayette & Lafayette & Florida & Florida \\
\hline Year & Count & Rate & Count & Rate \\
\hline 2018 & 18 & $1,560.50$ & 79,639 & 3372.1 \\
\hline 2017 & 13 & $1,076.70$ & 80,227 & 3492.1 \\
\hline 2016 & 13 & $1,097.20$ & 75,826 & 3341.6 \\
\hline
\end{tabular}




\section{Bacterial STD Rates in Lafayette County Alumni Ages 19-27}

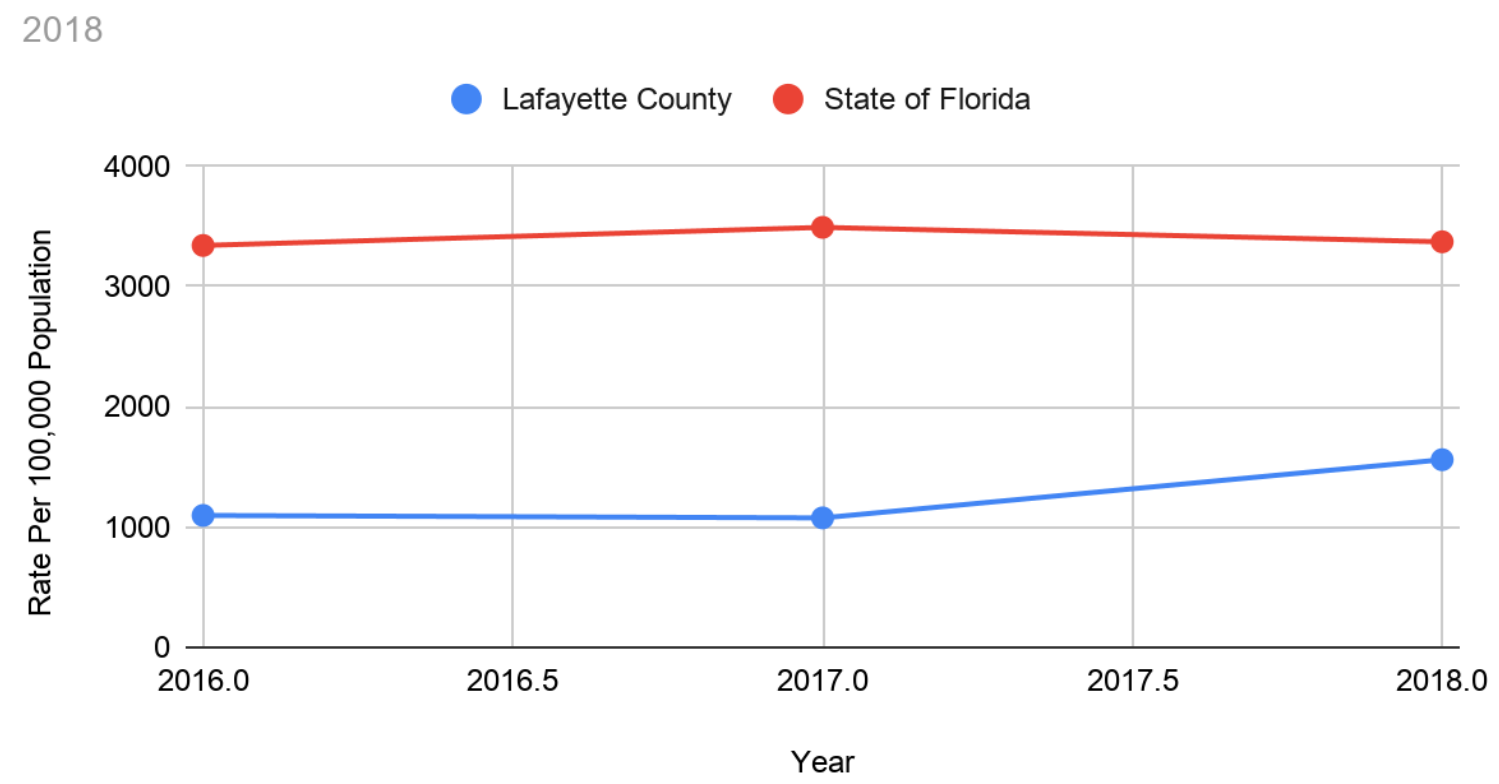

Figure 2: Information sourced from FLHealthCharts.com, 2020

\section{Martin County}

Once I reviewed Martin County's curriculum I found that it was centered on an abstinence-only approach to teach its alumni ages 19-27. While I was going through the PowerPoint provided to me directly from Martin County, I noticed that although only mentioning the word abstinence twice, there was no mention whatsoever of preventative means of STDs, such as condoms, that could be employed by their students throughout their lifetimes. The STD portion of the Health Outcomes, Planning and Education (HOPE) PowerPoint used in the county vastly covered several bacterial STDs, their symptoms, and their transmission throughout a total of 19 slides, yet discussed prevention of them on only 1 of those slides.

The prevention slide is centered around Chlamydia, Herpes, Syphilis and Gonorrhea and has three bullets points. The first states that the "body does not build up an immunity to any STD," the second states that "no vaccination is available to prevent these diseases," and the third states that "abstinence is the only choice that is $100 \%$ effective in preventing the spread of STDs." As previously brought up, due to the curriculum's failure to mention any other means of contraception and/or means of prevention, it is strongly classified as abstinence-only. After classifying Martin County's curriculum, the amount of bacterial sexually transmitted diseases found within the graduates from the years 2009-2017 was examined and compared to Florida's overall rate (Table 3). Martin County's bacterial STD rates among their alumni ages 19-27 are significantly lower than the state of Florida's overall bacterial STD rates throughout 2016-2018 (Figure 3). 
Table 3: Information sourced from FLHealthCharts.com, 2020

\begin{tabular}{|c|c|c|c|c|}
\hline \multicolumn{5}{|c|}{ Bacterial STDs, Ages 19 - 27, Rate Per 100,000 Population, Single Year } \\
\hline & Martin & Martin & Florida & Florida \\
\hline Year & Count & Rate & Count & Rate \\
\hline 2018 & 248 & $1,943.00$ & 79,639 & 3372.1 \\
\hline 2017 & 243 & $1,959.10$ & 80,227 & 3492.1 \\
\hline 2016 & 253 & $1,971.20$ & 75,826 & 3341.6 \\
\hline
\end{tabular}

\section{Bacterial STD Rates in Martin County Alumni Ages 19-27}

\section{8}

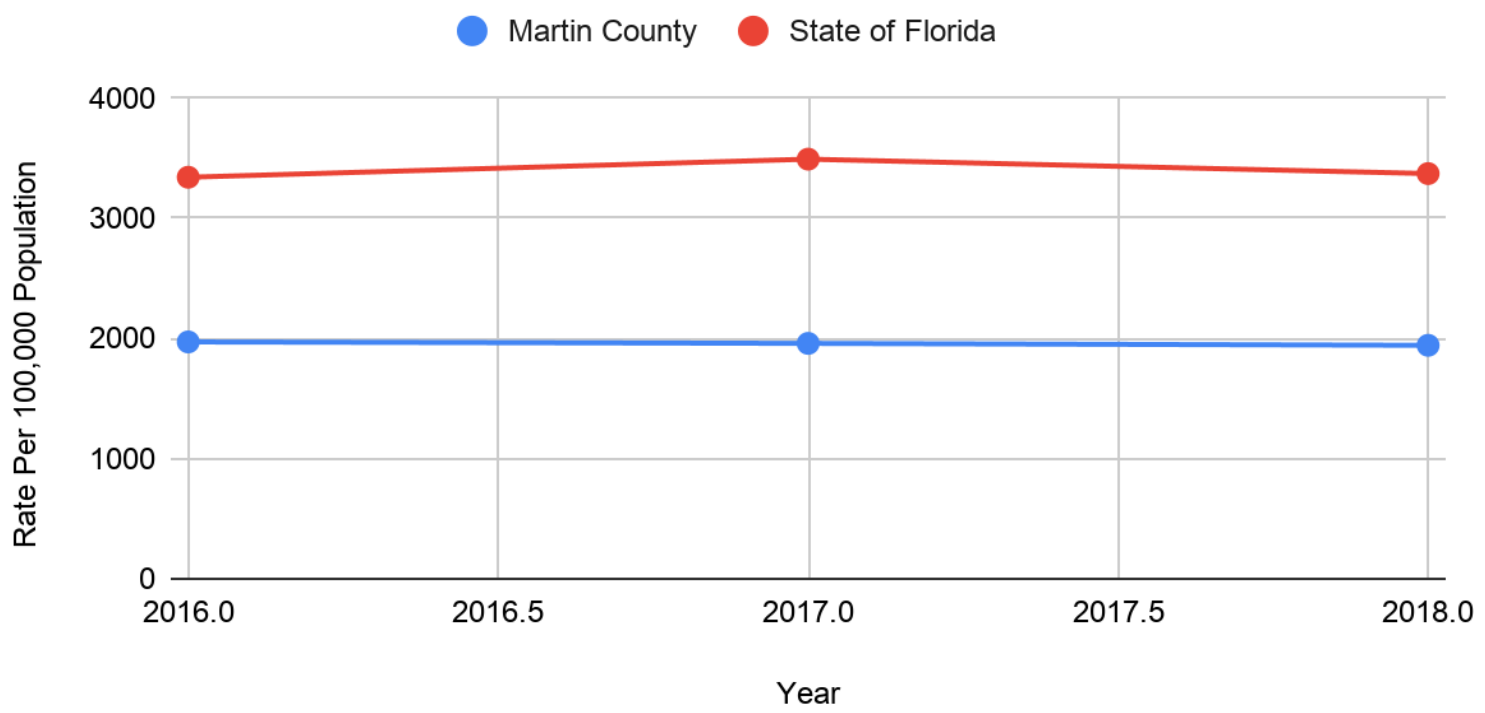

Figure 3: Information sourced from FLHealthCharts.com, 2020

\section{Orange County}

Orange County employed an abstinence plus program to educate their alumni ages 19-27. This outcome was derived from the STD powerpoint Orange County used to teach their alumni as well as the individual benchmark standard documents Orange County follows. The powerpoint alone only mentions the term "abstinence" one time and the term "abstain" 12 times. Each of those 12 times that the term "abstain" is brought up in the powerpoint, it is in a bullet point for a different sexually transmitted disease and used to discuss "abstaining from sexual contact" from others who tested positive. The term "condom" is also mentioned 12 times in the powerpoint provided by Orange County and can be found following the bullet points discussing abstinence as a preventative method against sexually 
transmitted diseases. At first, when solely analyzing the powerpoint applied in the county it appears to possibly employ a comprehensive program because no apparent moral bias comes through when the topic abstinence is taught; nevertheless, after sorting through and analyzing other documents a slight moral bias is discovered. The advocacy of abstinence was found within the Orange County Public School (OCPS) Life Management Skills/Health Opportunities Through Physical Education file regarding abstinence as one of the benchmarks in the entire health curriculum.

The OCPS benchmark standards require students to complete an activity where they list all the benefits of abstaining from sexual activity and then sit through a short briefing given by the instructor highlighting a specific set of benefits. In the list of these benefits that are required by the county to be taught include, but are not limited to, teens being "free to develop a respect for self," "free from guilt, doubt, disappointment, worry, rejection, etc.," "free from exploitation," and "free to enjoy being a teenager." The inclusion of these benefits, that are based mainly in feeling, suggest to the students being taught to them that if they are not abstinent that they will experience the opposite of these: losing respect for themselves, feeling guilty and/or regretful, being objectified and used, and being unable to enjoy what little time they have as a teenager. Clearly, while educating their alumni ages 19-27, Orange County Public Schools also promoted that they remain abstinent by infusing the sex education curriculum with pro-abstinence ideals. This is why the curriculum is classified as abstinence-plus. After analyzing Orange County's curriculum, the number of bacterial sexually transmitted diseases found within the graduates from the years 2009-2017 was observed and compared with Florida's overall rate(Table 4). It was found that Orange County's bacterial STD rates among their alumni ages 19-27 were slightly higher than the state of Florida's bacterial STD rates from 2016-2018(Figure 4).

Table 4: Information sourced from FLHealthCharts.com, 2020

\begin{tabular}{|c|c|c|c|c|}
\hline \multicolumn{6}{|c|}{ Bacterial STDs, Ages 19 - 27, Rate Per 100,000 Population, Single Year } \\
\hline & Orange & Orange & Florida & Florida \\
\hline Year & Count & Rate & Count & Rate \\
\hline 2018 & 7,723 & $3,870.70$ & 79,639 & 3372.1 \\
\hline 2017 & 7,745 & $4,078.20$ & 80,227 & 3492.1 \\
\hline 2016 & 6,660 & $3,643.30$ & 75,826 & 3341.6 \\
\hline
\end{tabular}




\section{Bacterial STD Rates in Orange County Alumni Ages 19-27} 2018

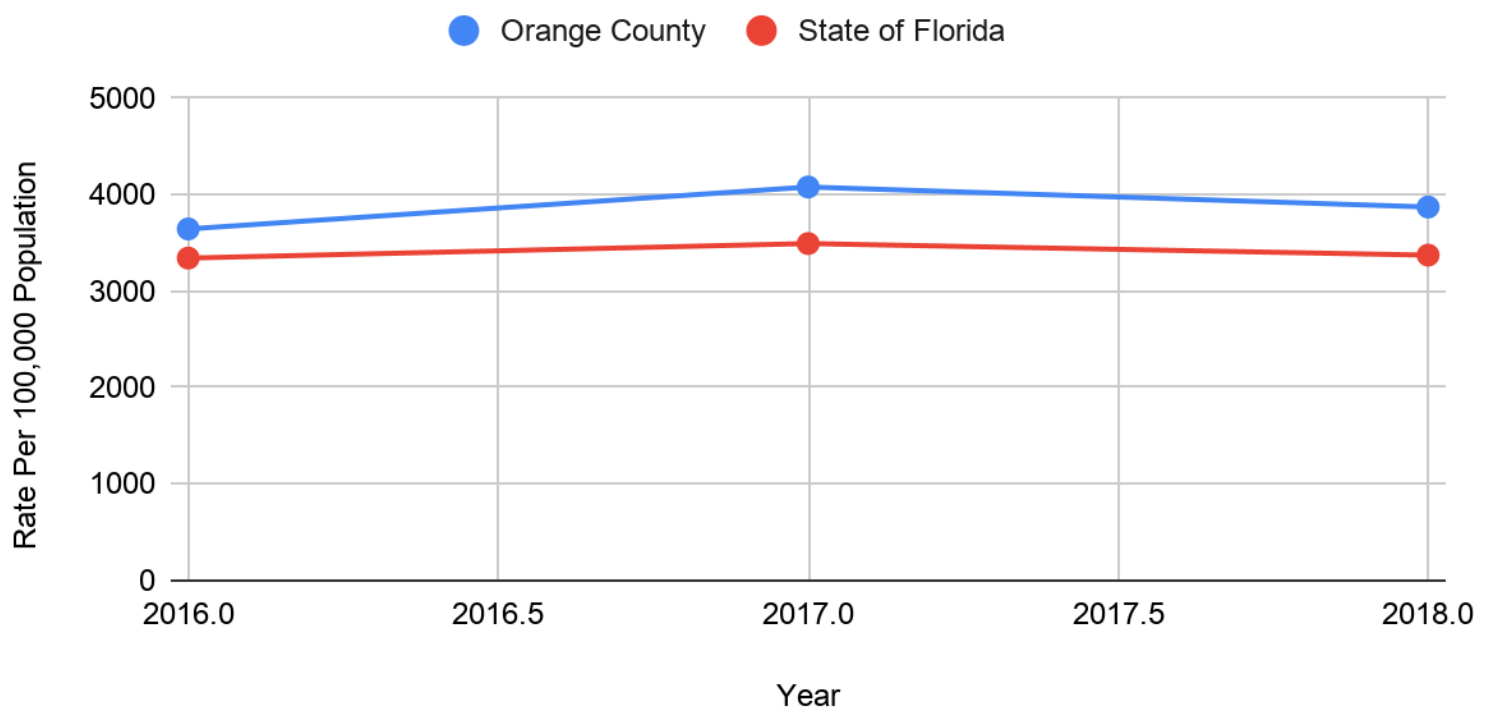

Figure 4: Information sourced from FLHealthCharts.com, 2020

\section{Polk County}

Polk County, unlike all the other counties, used a comprehensive sex education program to teach their alumni ages 19-27. The type of program Polk County high school's used was concluded succeeding the investigation of the sex eduction lesson plan and powerpoint issued by the county board. In the powerpoint presented to the previous group of students being researched, the terms "abstinence" and "condom" appear the same amount of times: 3 . When talking about abstinence, the powerpoint displays no moral undertones or bias toward the particular STD prevention method. Also, when discussing condoms in the powerpoint, there is no sign of bias against them. Facts rather than feelings are used when both preventative measures are exhibited. For example, in terms of abstinence, the powerpoint states that abstinence is the best decision for teens because it is $100 \%$ effective, completely free, and it prevents all STDs. All of these points are completely accurate and were constructed with no prejudice. Furthermore, the lesson plan doesn't have a specific section dedicated to educating students on abstinence but one instead on "ways to prevent the spread of STD/STIs as a whole. So, in accordance with the definition of comprehensive sexual education, Polk's program is justifiably included on that spectrum. Once the analysis of the curriculum commenced, it was found that the bacterial STD rates among the graduate classes of 2009-2017 in Polk County was extremely similar to the overall rates in Florida (Table 5). The statistics are almost identical and indicate little variance (Figure 5). 
Table 5: Source: FLHealthCharts.com, 2020

\begin{tabular}{|c|c|c|c|c|}
\hline \multicolumn{5}{|c|}{ Bacterial STDs, Ages 19 - 27, Rate Per 100,000 Population, Single Year } \\
\hline & Polk & Polk & Florida & Florida \\
\hline Year & Count & Rate & Count & Rate \\
\hline 2018 & 2,585 & $3,369.00$ & 79,639 & 3372.1 \\
\hline 2017 & 2,601 & $3,515.80$ & 80,227 & 3492.1 \\
\hline 2016 & 2,494 & $3,401.50$ & 75,826 & 3341.6 \\
\hline
\end{tabular}

\section{Bacterial STD Rates in Polk County Alumni 19-27}

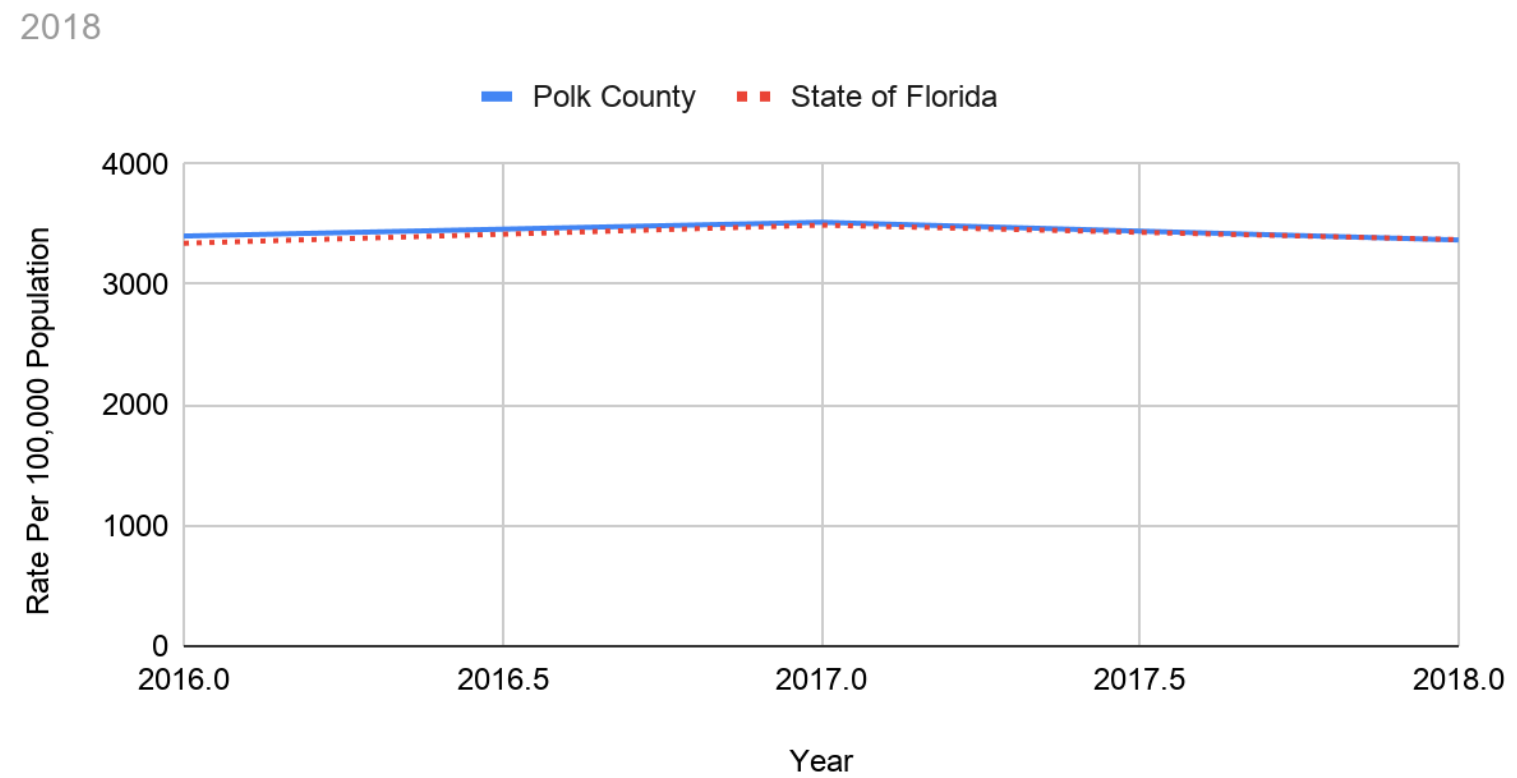

Figure 5: Source: FLHealthCharts.com, 2020

\section{Trends}

The first pattern detected was between illiberal, abstinence-only curriculums resulting in lower amounts of bacterial STDs found within their alumni and higher numbers resulting from more liberal curriculums(abstinence-plus and comprehensive) being taught. The relationship the curriculum types have with the amount of bacterial sexually transmitted diseases indicates when teens receive information about preventative methods, bacterial STD cases increase. However, the introduction of preventative measures in the curriculum is not to be confused with the idea presented to teens that engaging in sexual activity is acceptable. Orange County had the highest number of bacterial STD cases yet advocated for abstinence in addition to discussing means to prevent STD transmission during sex. While Polk County had less cases of bacterial STDs than Orange County and merely mentioned abstinence and approached teens engaging 
in sexual intercourse as a more accepted concept. A possible reason for Orange County possessing the highest amount of bacterial STD cases in their graduate class of 2009-2017 among the data is the county's idea that teens engaging in sexual activity is somewhat unacceptable. In Orange County, the alumni who were taught through the abstinence-plus system may feel a sense of shame when trying to acquire contraceptives, such as condoms. Usually, a county's sex education program reflects the widespread belief of the adults residing in the county. Orange County Public High School alumni may be deterred or feel awkward purchasing contraceptives due to the moral environment they are in. The same principle can be applied to Polk County but reversed. The alumni who were educated in Polk County were informed in a safer, more accepting climate and can possibly feel more comfortable purchasing contraceptives that prevent STD transference. Hence why Polk County alumni ages 19-27 suffered fewer cases of bacterial sexually transmitted diseases.

A minor trend observed throughout the data is the correlation between the location of the counties and the programs they used. Lafayette County and Martin County are the most North overall and implemented the most conservative programs, whereas Orange County and Polk County are more centrally located within the state of Florida and implemented more liberal programs. The counties' locations relate directly back to the idea of the alumni being raised in a climate where sexual activity outside of marriage is more accepted or shamed. The more North one moves in Florida the closer to the Bible Belt they become. The Bible Belt is an area mainly in the southern region of the United States inhabited by a majority of people who are allegiant to the Bible scriptures (Merriam-Webster, 2020). Logically, the counties further north(Lafayette and Martin) are more likely to have moral climates influenced by religious beliefs. The large and more prevalent presence of religion possibly impacting both Lafayette and Martin County support why they implemented more inflexible, consrvative sex education programs and maintained lower numbers compared to the two more centrally located counties.

\section{Analysis}

Being that the most comprehensive program was shown to be the least effective in reducing the cases of bacterial sexually transmitted diseases among alumni ages 19-27, other counties around the United States that believe comprehensive education is the most effective may want to rethink their decision. Although not what I originally expected, the results found were more than satisfactory in completing my goal. More specifically, my goal was to uncover correlations throughout people's rates of contracting bacterial STDs based off of what sex education they received and that was accurately completed. My results have steadily allowed me to come to a well-supported conclusion, completely satisfying my original intent.

\section{Implications}

The implications of my research lie not only in the realm of sexual health but also in the realm of psychology, and educational environments. In terms of psychology, after teachers or researchers review my results, they may choose to employ different psychological techniques to deliver information to students. Looking more at the educational environment, schools may rethink what programs they use to teach their kids and that will not only change the 
atmosphere in sex ed classes but around the entire school. When multiple children's moral foundations are altered, often the atmosphere in places those children reside will change; either for the worse or for the better depending on the situation.

\section{Limitations}

Only compiling data analyses from 4 counties in Florida rather than a wider selection limited the results in my data. Since Florida has 67 counties in total, my analysis of only 4 of them simply cannot provide the best possible research, although it is accurate for those 4 areas. Originally, to counter this limitation I sought to analyze 8 counties; however, I was only provided information to analyze for 4 . In the future, to combat this limitation, it would be ideal to survey more counties in Florida under the same premise, if not all. Another limitation within my results is the fact that I only measured one abstinence-plus curriculum and one comprehensive curriculum. The correlations and conclusions I drew may have been affected by different variables, causing it to seem as if the sexual education program type directly impacted the bacterial STD rates being measured. By investigating multiple counties that implemented the same type of sex education program, there would be a better, more accurate representation of the effect the content and ideals within the program had on the rate of bacterial STDs contracted in the specified graduate classes. Ideally, multiple counties would be analyzed for each of the three different types of sex education curriculums.

\section{Conclusion}

To summarize the data, the main correlation between bacterial STD rates among the alumni of the 4 counties, ages 19-27, and the sex education used in the corresponding educational institution is that abstinence-only curriculums yield lower amounts of STDs than abstinence-plus and/or comprehensive curriculums. Prior to conducting a metaanalysis, I hypothesized that the abstinence-only curricula would demonstrate higher bacterial STD rates when compared with the statistics from the alumni who attended school districts that implemented abstinence-plus and/or comprehensive programs. Nonetheless, my hypothesis was incorrect and actually the opposite of my investigation's outcome, despite being based on previous knowledge gained from past studies.

Numerous studies point out that comprehensive sexual education usually reduces the number of bacterial STDs; however, my findings after conducting thorough research have found otherwise. Since my study has become somewhat of an outlier in my field, it begs the question of what other variables may affect a sex education program's success rate. Researchers may begin to ask themselves similar questions, leading to more research being done in the same or similar manner, and possibly leaving newly accepted wide-spread findings to be concurred. In the future, the optimal next steps for this research to further develop would be to carry out the same analysis in as many counties in Florida as possible. Preferably, all the counties will be able to be analyzed to see correlations between sex education programs and bacterial STD rates. By doing so, this will complete the research question's full potential and provide a thorough analysis of all of Florida's sex education programs. Not only will these steps unlock the research questions full potential, but they will also fill in more gaps the in field 
The entire process of my investigation was enlightening and fueled by curiosity and determination. While completing the process, getting a hold of the curriculums themselves had to be one of the most painstaking parts as well as coming up with a brand-new research question after my original one failed twice.

\section{Acknowledgements}

Upon publication of my first research paper, I would like to thank all of my friends, my family, and my advisor. These people believed in me throughout the duration of writing my paper and all the ups and downs that I experienced as a young researcher. I want to give a special thanks to my advisor Mrs. Williams and a very special friend of mine named Ariana Labrada. Mrs. Williams taught me that hitting walls is all a part of a researchers' journey and even when it seems as if all hope is lost, there is always another way. Not only that, but she also taught me that you have to follow your passion and research what you love. Creating a 30 page paper from scratch is hard enough in itself but if I hadn't taken her advice and gone with a topic more accepted by my parents, I would have probably given up, thank you Mrs. Williams. Ariana, better known as Ary, taught me to never give up. Having her by my side in class, after school, and on facetime during the late hours of the night while we both completed our papers really pushed me to see everything through to the end. Ary, I would have never been able to do this without you and I could never have asked for a better AP Research buddy! Lastly, I thank you, for reading my paper and supporting my work. Without an audience to read it, a paper's contents may as well have not even existed. I hope you enjoy the results of my tears, sweat, and early onset carpal tunnel(feel free to laugh at my attempt at making a joke)!

\section{References}

Alford, S. (2001). Sex Education Programs: Definitions \& Point-by-Point Comparison.

Retrieved May 26, 2020, from https://advocatesforyouth.org/resources/fact-sheets/sex-education-programs-definitons-and-point-by-point-comparison/

Blanton, N. (2019, October 10). Why Sex Education in the United States Needs an Update and How to Do It. Retrieved April 14, 2020, from https://scholars.org/contribution/why-sex-education-united-states-needs-update-an -how-do-it

Boonstra HD. Advocates call for a new approach after the era of 'Abstinence-Only' sex education. Guttmacher Policy Rev. 2009

Center of Disease Control. (2019, August 20). STD Facts - Human papillomavirus (HPV). Retrieved April 27, 2020, from https://www.cdc.gov/std/hpv/stdfact-hpv.htm 
Florida Department of Education. (2020). Statutes, Policies \& Guidelines. Retrieved April 27, 2020, from http://www.fldoe.org/schools/healthy-schools/sexual-edu/policies.stml

Gross, L. (2017, November 21). STDs at record high across US, Florida ranked in top 10 states. Retrieved December 12, 2019, from https://www.wfla.com/news/florida/stds-at-record- high-across-us-florida-ranked-in-top-10-s tates/.

Hall KS, McDermott Sales J, Komro KA, Santelli J. The State of Sex Education in the United States. J Adolesc Health. 2016;58(6):595-597. doi:10.1016/j.jadohealth.2016.03.032

HHS Office of the Secretary,Office of Infectious Disease. (2019, November 20). Sexually Transmitted Infections (STIs). Retrieved April 27, 2020, from https://www.hhs.gov/programs/topic-sites/sexually-transmitted-infections/index.html

Jemmott, J. B., 3rd, Jemmott, L. S., \& Fong, G. T. (2010). Efficacy of a theory-based abstinence-only intervention over 24 months: a randomized controlled trial with young adolescents. Archives of pediatrics \& adolescent medicine, 164(2), 152-159. https://doi.org/10.1001/archpediatrics.2009.267

March of Dimes. (2018, January). Sexually transmitted infections. Retrieved April 27, 2020, from https://www.marchofdimes.org/complications/sexually-transmitted-infections.aspx

Martin County Public Schools. (2006). HOPE High School Curriculum. file://C:/Users/17542/Downloads/HOPE\%20Unit\%20PPs.pdf

Masutier, Valerie, "Sexually Transmitted Disease Rates and Sexual Education Programs in the Georgia School System." Thesis, Georgia State University, 2017. https://scholarworks.gsu.edu/anthro hontheses/16

Merriam-Webster. (n.d.). Bible Belt. In Merriam-Webster.com dictionary. Retrieved May 26, 2020, from https://www.merriam-webster.com/dictionary/Bible\%20Belt

Orange County Public Schools. (2009). Common Sexually Transmitted Diseases(STDs) High School Version. https:/docs.google.com/presenttion/d/1SwrAyK3pE910oTLyNEdAInw JdDazMymci6VWQN4Zjw/edit?usp=shari ng Orange County Public Schools. (2020). OCPS LIFE MANAGEMENT SKILLS/HEALTH OPPORTUNITIES THROUGH PHYSICAL EDUCATION. file://C:/Users/17542/Downloads/Abstinence-PostponingSexualActivity.pdf 
Orange County Public Schools. (2020). OCPS LIFE MANAGEMENT SKILLS/HEALTH OPPORTUNITIES THROUGH PHYSICAL EDUCATION (HEALTH PORTION) BENCHMARKS.

https://mailattachment.googleusercontent.com/attach-

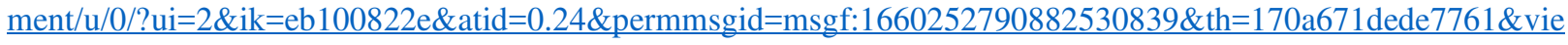
$\underline{w}=$ att \&disp $=$ inline $\&$ saddbat $=$ ANGjdJ8b1HWa6VKkupP1ak11Wn-

llW0lqmW mkUUPZmXncnbVf4E2zDTdOzQQr57hkkUbznPMR4eQ4cO89FspxC3kjBIKdzENNB1brc Nxp0 MEGaSGZ9tX0Yy5ZaKIFw69vaHoSaT8L0vBJmWO5W1vnSZ1b2efxuCibt9OedI7QM6J5uXvALcumRtdecLEKN16oZAJsGFfZsdFaqI49uATbn5 N66vxAW5Q irEff6PG8dsjxw2 WQXxrJKH8JvDy0CeLTW1jjIh1C1nqRw5o24oucZjbLjV8OMAPkY3VZmFsW S8XRSUHmqYr3PHQzkQCm wPN jDf8 5n3poiANSvTUUqb9TAmB5k4A GhkGRjQB5t2SmK30R0mZRw91BlS7rPjJmvx4Kbqfo0iYQ2uwxdjbzjyStDrArHpOiz9u9dTFpSFem2WFP AH25qnP9qcRy5TimZNyFxMLDWmaaoBZaU664 jGrxtPcBlKe8csovTSu6Zn MjLE8vvvVLUji iOQUHJDmNMgjFyj70vrBjoXamSvQ iekgzhzS5eYEm pQFLIAPOt64zYcvewNdPD8TUsZfUE9H CSYE8Fns cp58u3ZNAGjwFZYYLXvvFe5RMXIzJR A32XZDkbn2p4SHQ7ysK5n85dwkK8mAW NZHc0qDZtRgUxLkpTafDw 7gics

Phelps, Scott. (2001). A.C. Green's Game Plan. Abstinence and Marriage Education

Partnership

Polk County Public Schools. (2019). Polk County High School Lesson Topics.

https://mail.google.com/mail/u/0/?tab=rm\&ogbl\#label/AP+Research+CurriculumsKtbxLxgZdQBIDHSrPTGMLzpnTRDCpQxFIV?projector=1\&messagePartId=0.1

Polk County Public Schools. (2016). High School Powerpoint Combined Topics https://docs.google.com/document/d/1XnUuvBxPN3FQNEvLzLGuTQfuq1Nu fBJNmX18YosXw/edit?usp=sharing

Silva, M. (2002). The effectiveness of school-based sex education programs in the promotion of abstinent behavior: a meta-analysis. Health Education Research, 17(4), 471-481. doi: 10.1093/her/17.4.471

Smith, S. K. (2005). Florida Population Growth: Past, Present and Future. Dissertation Abstracts International, Vol. 1,36

Stanger-Hall, K. F., \& Hall, D. W. (2011). Abstinence-only education and teen pregnancy rates: why we need comprehensive sex education in the U.S. PloS one, 6(10), e24658. https://doi.org/10.1371/journal.pone.0024658 